\title{
FISHERIES EXPLOITATION OFF CANADA'S WEST COAST: THE EFFECTS OF NATIONAL POLICY
}

\section{by Parzival Copes*}

\section{INTRODUCTION}

Over the past three decades there has heen a manifold increase in the exploitation effort applied to the world's marint fish stocks. By the end of the 1960s there were clear signs of biological overtishing for mitty of the more desirable and accessible stocks: annual catches were declining despite increasing fishing effurt. Recognition of this irrational use of the world's lish resources led to attempts at corrective action in two spheres. Domestically, several countries introduced management meatsures that regulaled fishing etfort, with the aim both of conserving stocks and of improving economic returns to the fishing industry.

In the international sphere. states whose tishing activities liacused on their own coastal contes. pensed foi iecognition of preferential access for coastal states to the fish resources adjacent to their shores. Their agitation culminated in a rash of unilateral declarations of extended lishiog junisdistitin laking affect in 1977 . In that year the 200 -mile lishing limit became the accepted world standard and, thereby, an article of international law. There were two principal arguments tor extended coastal state jurisdiction. One was that the only practicable way of brifging fiok stocks under effective mungement was to place them under the legal atuthority of particular states. The other was that coastal states should hold first rights to adjicent lish stocks, on which their coastal communities were often economically dependent (Copes [K]).

This paper will consider the changes that are taking place in tishing operations off Canada's west coast following the establishment of extended fisheries jurisdiction. It will seck to analyze developments in relation to the policy objectives set by the Canadian government and the practical constraints that have been encountered." The analysis recognizes two spheres of action: one con= cerned with management of domestic fisheries and the other with foreign tisherics arrangements.

* The authur is Professor of Feconomiss at Simon Fraser Unjversity. Kesearch support from the Social Sciences and Humanities Research Council of Canada and helplul comments from $K . S$. Ketchen and J. McIßonaidi are graten̈ully acknowledged.

' Reference here is to the policy objectives exhibited by the Liberal Government that has held office since I\$33, cxcept for a short break belween the elections of June 1979 and February 1980. The Progressive-Conservative Government that held office during the break did not have time to consider any ulternative policy ohjectives. 


\section{The Domestic Fisheries of British Columbia}

Canada's west coast province of British Columbia was late to be colonized and developed because of $\mathrm{its}$ remote location in relation to the path of European migration to and through Norh America. The conditions affecling economic development in the province include a rich natural resource base, at small population and a long distance to world markets. Under these circumstances only the richest among the available resources tend to be exploited, at least at first.

The marine resources of Canada's west coast include abundant stocks of salmon, a high-value food fish that can be harvested at low cost. Salmon naturally became the first and most important target species of the British Columbia fishing industry. While fisheries for other species are now well developed, the salmon sector remains dominant. It accounted for a landed value of $\$ 109$ million in 1977 , comprising 65 percent of the catch value for Canada's west coast and 24 percent of the value for cast and west coasts combined. This makes the Pacific satmon sector easily the most valuable component of Canada's fishing industry.

The halibut lishery, historically, has also been prominent in British Columbia. Halibut is a high-value food tish, though not quite on a par with salmon. Moreover, the halibut stocks are much smaller in extent than the salmon stocks, so that halibut has always ranked well behind salmon in importance.

In physical terms of biomass, British Columbia"s stocks of herring are much greater than those of salmon. But with a very much lower unit value for the catches and great variations in abundance, the herring fishery has been a less steady sector of the industry. In the last few years, the British Columbia herring stocks, which are particularly well stited tó noe puduclion, have laken on a new importance, second only to salmon. A spectacular speculative surge of herring roe prices in the Japanese market has made this lishery quite lucrative - at least for the lime being.

There is one further sector of the British Columbia fishing industry of some significance. This is a trawl fishery for smaller groundlish, i.e., species other than halibut." They include various "cods," small llatfishes, ocein perch and other rockfishes. These are more modestly priced species supplied particularly to local fresh fish markets, though some quantities of processed frozen products are shipped to distant markets. The yield potential in the past substantially exceeded the harvesting requirements of the domestic fishing industry for the available market. However, in the last few years domestic explotation of all of the more important species has reached the level of full utilization.

A few minor fisheries require mention. Modest stocks ol various shellish (oyster, clam, crab, shrimp and prawn) along Canada's west coast have been brought under exploitation in response to high demand for these luxury species. Migrating stocks of albacore appear in British Columbia waters with varying annual abundance. They are an attractive fisheries target when available in suîicient numbers (Copes [12]). I ess attractive is a resident slock of dogfish.

\footnotetext{
"Unless the context indicates otherwise, "groundfigh" in this paper does not include halibut.
} 
a nuisance predator on more valuable species. However, a fishery lor dogfish appears commercially feasible and is being developed.

\section{The loretgn Interface}

Institutionilly, an important aspect of fisheries on the west coast ol North America has been the interaction, and sometimes integration of, Canadian and American operations. Both countries have been fishing the same northeast Pacific stock complexes. These extend from the British Columbia zone into American waters, nothwards into Alaska and southwards into Washington, Oregon and, to a lesser extent, California. The commercially most important species in this northeast Pacific marine region, salmon and halibut, ate characterized by regular migrations, with a large patt of the stocks passing through both American and Canadian 200-mile zones.

Inevitably, fishermen from each country have been taking large amounts of fish, which, it not intercepted by them, would have ended up in the nets of fishermen from the other country. Moreover, in the past Canadian and American vessels have operated freely off each other"s coasts outside the original threemile limits, in pursuit of the best exploitable concentrations of fish wherever these might be found. As illustration of the foregoing, it may be noted that for a long lime Americans have been taking about half of the rich sockeyt and pink salmon runs heading for the traser River in Canada, while Canadian fishermen a few years ago were taking the larger part ol their halibut catch from Aluskan waters.

Because of heavy exploilation of the satmon and halibul stocks in the northeast Pacilic, hoth Canada and the United states have long recognized a need for conservation measures. And because of the joint exploitation palterns the two countries were induced to establish joint conservalion agencies (Koers [20]). In 1923 they atgreed to set up the International Pacilic Halibut Commission (IPHC). This body has regulated exploitation, principally by the device of setting annually a limit on the total catch for the combined fishing fleets of the two comntries.

The International Pacific Salmon Fisheries Commission (IPSH') was established by a convention signed in 1930, though its implementition was delayed until 1937 (Koers [20]). 'The Commission's task was to improve the joint catch from the potentially very abundant stock of sockeye salmon using the firaser River system for spawning. In 1957 the pink salmon runs of the same river system (together with those of adjacent smaller streams on both sides of the border) were also placed under the Commission's authority. The salmon approached the Fraser River in British Columbia through waters straddling the marine boundary of the two countries, where they were subject to a joint fishing effort. The agreement called for a 50-50 split in the allowable catch, as well as an even split in the cost of improving salmon passage and rearing on the Fraser River.

The policy of accommodation in their joint exploitation of fisheries was continued after the two countries moved to establish 12-mile fishing zones. They 
allowed reciprocit aceess for each other's fishermen to grounds within the 12 mile fishing limit, bul outside the three-mile territorial limit ${ }^{3}$ However, the coming ol the 200 -mile limit has marked the beginning of new and much more restriclive policies on mutual fisheries accommodation, which will be discussed below.

Prior to 1965 the fishery off British Columbia was pursued exclusively by Canadian and American vessels. But in that year a Soviet fishing flect appeared. It was joined the following year by a Japanese tleet. Both engaged in a factory trawler tishery for groundfish species. Canadian concern over the appearance of these foreign fleets wis moderated by the fact that the groundfish stocks were in excess of North American harvesting requirements and that the Soviets and the Japanese were apparently not engaged in any directed fishery for salmon or halihut. The salmon fishery, in any case, was best pursued by smaller vessels, mostly inside the 12-mile limit from which the Soviets and Japanese were barred. 'The halibut fishery was hest undertaken by smaller vessels using longlines. How. ever, it was subsequently concluded that the Soviet and Japanese trawling operations did cause damige to the halibut fishery by removing part of the juvenile halibut stock (Hoag [18]).

The fleets from the U.S.S.R. and Japan fished vigorously off Canada's Pacific Coast during the ten years, 1966-1975, reducing the local groundtish stocks considerably in the process. In 1975 they were joined by a Polish fleet, as well as a lew vessels from the Republic of Korea (South Korea) and the German Democratic Republic (East Germany). 'Jhe following total groundfish catch estimates for the period, 1966-1975, show the dominance of foreign fleet operations in this sector."

$\begin{array}{lcc}\text { Country } & \begin{array}{c}\text { Catch } \\ \text { (metrictons) }\end{array} & \text { Percent } \\ \text { Canatit } & 187,468 & 2.9 \\ \text { U.S.A. } & 132,687 & 16.9 \\ \text { U.S.S.R. } & 270,612 & 34.5 \\ \text { Japan } & 163,621 & 20.9 \\ \text { Poland } & 26,273 & 3.4 \\ \text { R.O.K. } & 1,301 & 0.2 \\ \text { G.D.R. } & 2,000 & 0.3\end{array}$

By 1976 it was evident that rockfish species (particularly ocean perch) had been over-exploited and that the halibut stocks had suffered from trawling operations. This provided Canada with an incentive to limit foreign groundfish operations when the 200-mile limit was introduced in 1977. This is discussed below.

\footnotetext{
These reciprocial privileges were also extended to American fishermen when Canada in 1970 claimed fisheries jurisdiction in certain additional waters behind "fisheries closing lines."

- Data provided by K. S. Ketchen, Pacific Biological Station, Canada, Department of Fisheries and Oceans.
} 


\section{The Rationalization of Domestic Fisheries}

In 1976 the Canadian government issued a document entitled, I'slicy for Canada's Commerical Fisheries. It contained an extensive analysis of the prevailing problems of the Canadian fishing industry. as well as principles and guidelines for redevelopment. It was, in fact, the first ever comprehensive statement by a Canadian government on fisheries policy. 'The timing of its publication was explicitly linked, both to the acute conditions of crisis then existing in the Atlantic Coast fisheries and to the imminent establishment of the 200-mile limit. The document made explicit a policy of socio-economic rationalization of the Canadian fishing industry, which had heen emerging over the previous 12 years (Copes [9]).

Canadian fisheries problems have been largely of the same character as those of mature fisheries elsewhere in the world. The central difticulty has been the peculiar condition of economic exploitation of fish stocks as a "common property resource." "The problem. in its wider conlext, has become known as "the tratuedy of the commons" (Hardin [17]). It was only when Gordon in 1954 published his seminal article, that a start was made with a careful and extensive economic analysis of the fisheries problem. Gordon's interest in the fisheries problem was related to a stint as economic analyst with the Canadian government's Department of Fisheries. Canadian cconomists, in fact, have been prominent among the contributors to the analytical literature on fisheries economics that has developed over the past 25 years. Their influence helped to develop a growing understanding of the fisheries problem in the Canadian govermment service well in advance of such understanding in most other countries.

Before economists busied themselves with the fisheries question, biologists had identified the problem of overfishing in physical terms. They formulated the concept of maximum sustainable yield (MSY), which marked an optimum level of steady state exploitation in terms of physical output. Under their influence various methods of fisheries regulation or closure were put into effect to constrain fishing activities, with the aim of conserving stocks by lowering effective fishing pressure. When economists became involved, they identified as the key feature of the fisheries problem the practice of allowing open access to the common property fishery resource. leading to excessive inputs of manpower and equipmeat. The remedy was limitation and control of labour and capital inputs. The economic solution was to conserve not only the resource, but also the other factors used in the fishing process. so that economic returns could be maximized.

Under the influence of the new economic analysis of lisheries, the Canadian government in 1975 specifically adopted as a criterion for fisheries management the achievement of an optimum sustainable yield (OSY). It would maximize benefits in socio-economic terms, in contrast to the MSY which was designed to maximize the physical output of lish without reference to costs or benefits (Canada [4]; Copes [11]). This approach was confirmed in the 1976 policy statement. where the guiding principle in fisheries management was described as the "best. use of society"s resources" as defined "by the sum of net social benefits (per- 
sonal income, occupational oppostunity, consumer satisfaclion and so on) derived from the tisheries and the industries linked to them. "' The policy statement accepted the need to introduce restrictive licensing in all commercial fisheries.

The fisheries problem on Canada's eust coast was much more severe than on the west coast, primarily because in the east the lack of alternative employment opportunities tied greatly excessive numbers of men into the industry at exceplionally low opportunity costs. On the Pacific Coast wage levels were much higher and employment opportunities were more plentiful. Altogether, British Columbia fishermen, a high proportion of whom were urhan dwellers, were more mobile. All of this made rationalization of the fishing industry, involving a reduction of labour inputs, in the west more feasible - if perhaps less urgent - than in the east.

The first attempt by the Canadian government at comprehensive economic rationalization of a fisheries sector came in 1968; with the salmon fishery of British Columbia chosen as the object. There were three circumstances that made this a particularly suitable choice.

(1) As mentioned, there were relatively good alternative employment opportunities for fishermen displaced by ralionulization.

(2) The fishery, essentially, came under effective jurisdictional control of the Cantidian government.

(3) There was a demonstrably large benefit to be gained from rationalization.

The lishery for British Columbia satmon was undertaken largely by Canadian fishermen within the territorial limits of Canada or in international waters adjacent thereto. The Canadian government had full legal competence to control their activities. The only relevant fishing activity on a significant scale that could not be controlled by the Canadian government was the interception of Fraser River salmon by United States fishermen. But because there was a lirm agreement on a 50-50 split of this catch with the Americans, there was still no obstacle lo Canada rationalizing the fishery for her share of the catch. It is important to note that if the agreement had been for a tolal limit on each year's calch, with fishermen from either nation allowed to continue fishing until the year's limit was reached, effective rationalization of the Canadian fishery would not have been possible. For any reduction in the number of Canadian fishing units would then reduce Canada's share of the catch in the competitive scramble for fish. This latter was the case in the jointly managed halibut fishery, making it unsuituble for a rationalization scheme by one comntry.

\footnotetext{
$s$ The defined objective goes well beyond the familiar criterion of resource rent maximization oripinally set by Gordon (1954). It appears in line with the more elahorate eriterion of maximizing the combination of net social benefits consisting of resource rent, consumers' surplus and producers' surplus (Copes, 1972) and also takes industry linkages into account.

- Il should be ackrowledged that this generalization of the west coust situation is not valid for several smalt jsolated coastal settlements. Some native Indian communities, in particular, fall in this latter category.
} 
It was patently clear to everyone in the British Columbia salmon lishery that the numbers of fishermen and vessels in use were vastly in excess of the numbers required to take the entire catch. Conservalion measures to allow sutficient escapement of spawning salmon to renew the stocks were effected by frequent closures of the fishery. The severe restrictions on fishing time allowed made it plain to all concerned that if the number of vessels were smaller, more continuous employment could be achieved, with much higher catches per boat and much higher revenue per fishermitn.

Without the benefit of sophisticated economic analysis, the largest fishermen's organization in British Columbia, the United Fishermen and Allied Workers' Union (UFAWU), as early as 1943 reached the conclusion that the rational conduct of the salmon fishery required limitation of entry to the fishery. Later, an investigation of the question was commissioned by the Canadian government, resulting in a path-breaking study (Sinclair [26]) that advocated a limited entry scheme. Discussions between the government and the several elements of the industry revealed a consensus on the need for limited entry, but differences of opinion regarding the methods.

In 1968 the government put into effect a limited licensing plan. It barred some marginal vessels from the salmon fishery and provided for a "buy-back" program to remove additional vessels. Under this scheme fishermen were offered a sum representing an appraised value plus bonus to surrender their boat and license. The sales were on a voluntary basis entirely. The scheme was financed by increased license fees, justified by the higher returns remaining fishermen could expect from larger catches per vessel. ${ }^{7}$ The licensing and buy-back program has been hailed as a pioneering effort in fisheries rationalization, though the extent of its success is open to question (Pearse and Wilen [23]; Fraser. [14]). Increased returns in the salmon fishery since 1968 appear to have been more a result of higher prices than of effort limitation. All the same, there is now a broad consensus in the Canadian fishing industry that limited entry is a key requirement for economic improvement. Accordingly, license limitation has been introduced in all of the British Columbia fisheries.

The most effective and desirable form of license allocation remains a question of debate. In the salmon licensing program owners have been allowed freely to sell their boats with license attached. As a result, the rents represented by improved returns (real or anticipated) have been capitalized in license values. which have reached speculatively high levels. In turn this has rendered government buy-back of further vessels prohibitively expensive. In fact, as a result of this "expectations trap" the buy-back program was suspended after only five percent of catching capacity was removed from the fishery (Copes [9]). Much more than that amount of capacity has been built back into the fishery by technical improvements in the existing fleet (the process of "capital stuffing").

In view of the difficulty of removing excess fishing capacity by buy-back,

\footnotetext{
T For additional details see Pearse (1972) and Fraser (1977).
} 
governmenl plans now tend to emphasize increasing the fish supply instead, in order to raise calches and incomes per fisherman. In the case of the salmon fishery, a massive slock enhancement program has been commenced, designed to double the amount of fish produced, with the aid of hatcheries, artificial spawning channels, habitat improvement and other means (Canada [3]).

A problem in connection with enhancement is that much of the additional stocks would be liable to interception by American fishermen. But with the United States also planning an expansion of salmon enhancement programs, the converse would also be the case. Both countries naturally want a full return to their own nationals on any investment in enhancement. To achieve this there must be an agreement on compensation for interception or, alternatively, an agreement to seck it balance in interceptions (Copes [12]). Negotiations to this end are being conducted by the two countries.

Apart from salmon, Brilish Columbia marine fisheries do not offer much scope for stock enhancement. However, in the case of the halibut fishery there is a great need for an additional fish supply, as Canadian fishermen are losing access to the American $200=$ mile zone where they previously obtained the greater part of their catch. Canada's own hatibut slocks may be increased by careful regulation of trawling operations that previously did much to deplete halibut stocks. But there are also opportunities for Canadian fishermen to fish alternative species, in particular blackcod which may be taken by a setline fishery, similar to that for halibut. To this end the phasing ont of alt foreign fishing for hackood is anticinated.

There are, of course, further opportunities to increase Canadian catches of groundfish by replacing foreign effort. It is to be expected that the Canadian government will encourage existing fishermen lo expand their catches by fishing groundfish stocks previously explotted by foreign vessels, in preference to licensing additional fishermen to exploit these stocks. For an important aim of fisheries rationalization, of course, is to increase the catch, and thereby the net revenue of fishermen.

As indicated, the Canadian government is looking for opportunitics to expand Canadian catches of some species by replacing foreign effort. However, it should be noted that economic rationalization of mature fisheries previously subject to open access generally requires that catches and effort levels be kept below those compatible with MSY." It is interesting to speculate whether the combination of extended jurisdiction and the policy of rationalization will result

\footnotetext{
"This is the position exprested in most of the economics literuture from Gordon (1954) on, in which a steady state analysis is applied. Fssentially this is because marginu cutch (and murginul revenue) per unit of effort reaches 7ero at MSY. If marginal cost is not to exceed marginal reverue, effort and output levels must be kept below those compatible with MSY. This conclusion does not necessurily hold if a dynamic analysis with a positive social discarunt rate is used (Clark and Munro, 1975), In other words, we muy "overfish" if fish today is worth more then lish tumbrow. However, even with a dynamic analysis real price increases for diminished catches from physically averfished stotks may offset the effect of a pesitive discomt rate, and preserve the conclusion that effurt should be kept below the MSY level.
} 
in larger or smaller total catches from British Columbia tisheries. In the case of salmon and roe herring stocks that show a high schooling propensity (in estuarial waters or on spawning grounds) the OSY level is likely to be close to the MSY level. This is because marginal catching costs at MSY are likely to remain low as a result of fish density remaining high. ${ }^{9}$ In the case of salmon and herring the traditional management pattern of aiming for MSY therefore requires no significant modification. The policy of economic rationalization, as such, should make little difference on catch levels, though salmon enhancement and improved bioeconomic management of herring stocks could result in increased catches in both fisheries.

In the cuse of the more dispersed stocks of halibut and other groundfish, higher fishing effort undoubtedly tends to thin out the stocks. This should significantly lower catches per unit of effort and therehy raise costs per unit of catch. Optimum economic retums in these fisheries therefore is likely to be achieved at an output level measurably short of MSY. " If economic rationalization is successful, therefore, output levels from these stocks will be somewhat short of the maximum achievable under MSY management.

\section{The Regime of the 200 -Mile Limit}

Canada has enjoyed an enviable reputation as a middle power with a strong sense of international responsibility, tinged with "altruistic mission." The country's highly "internationalist" stance in foreign affairs during the days of Prime Minister Lester Pearson was modilied in some degree during the era of Prime Minister Pierre Trudeat. The development of strains within the Canadian federation called for a more conscious effort to reconcile foreign policy with the requirements of internal harmony and abatement of regional and sectional distress. This was reflected in Canada's position in international negotiations on the 1 aw of the Sea (Gollich and Dalfen [16]). While still seeking to maintain harmonious foreign relations and a favourable intemational image, Canada pushed strongly for changes in the $I$ aw of the Sea that were particularly supportive of her own national interests.

The coastal regions of Canada have long been vulnerable to a sense of distance from the country's central interests. To reduce regional alienation, particularly in the case of the distressed Atlantic Region, it was necessary to demonstrate a strong national concern for the particular problems of coastal regions. One of their visible concerns during the past decade was the rapid depletion of the fishery resources available to them as a result of escalating foreign fishing effort. This caused Canada to take an increasingly aggressive position in international negotiations on the Law of the Sea, pressing for recognition of greater coastal state rights in respect of nearby fish resources (Johnson [19]).

\footnotetext{
" Bel1 (1972) also observes thal standwd economic analysis shows that ccononic optimization will come closer to producing MSY at high levels of consumer denand for a lish stock. This certainly would apply to salmon and roc herritig.

1" lasticulaty so for groundfish species for which consumer demand is less high than for halihut
} 
Canada, in fact, assumed a leading role in developing new concepts of international law in relation to fisheries (Copes [9]). And as the international climate became more propitious, Canada shifted to increasingly more "acquisitive" positions. At the Third Law of the Sea Conference (which opened in 1974 and is still continuing through intermittent sessions) it soon became clear that a great majority of nations were ready to accept a 200 -mile fishing limit. A consensus on the appropriate conditions for such a limit was embodied in a document produced at the Conference. the Informal Composite Negotiating Text (ICNT). Disagreement on non-fisheries items in this document so far has prevented the conclusion of the conference and adoption of a formal convention. However, the 200-mile limit for fishing purposes has been adopted through the alternative process of a series of unilateral declarations by coastal states claiming these limits.

Many countries, including Canada (MacEachan [21]), have acknowledged that they will observe the rules formulated in the ICNT in administering their 200 -mile fishing zones. The ICNT accords to coastal states "sovereign rights for the purpose of exploring and exploiting. conserving and managing" the fish stocks in a 200-mile zone (United Nations, 1979). These rights are qualified, however, by the ICNT requirement that a coastal state, whicie it "dues not have the capacity to harvest the entire allowable catch" must "give other" states access to the surplus." "The constraint is not severe insofar as the ICNT allows the coastal state unilaterally to set the allowable catch, and thus determine the extent of the surplus - which could be zero. Moreover, the coastal state is entitled to set conditions of access to its zone - including fees - which could be prohibitive. The real constraint is a moral one. The coastal stale has a responsibility in the eyes of the international community to see to th that a vailable fish are not wasted. Thus the coastal state must be seen to be reasonable in setting realistic allowable catches and nonexcessive conditions of access.

One area of particular interest to Canada in the ICNT is the section dealing with "anadromous fish" which spawn in fresh water and spend much of their life in salt water." The ICNT rules have application only for those anadromous species (principally salmon) that migrate beyond the 200 -mile zones of their "states or origin." In the ICNT it is acknowledged that states of origin "have the primary interest in and responsibility for" anadromous stocks. It is widely acknowledged that states of origiin incu many explicit cosis in malntadning the spawning beds and freshwater habitat of salmon. They also face great implicit costs in having to avoid many alternative uses of salmon streams, e.g., for power development, irrigation and waste disposal. In addition it is known that the salmon fishery is managed most effectively, generally, if the catching operations are confined to waters near the mouths of spawning rivers. The salmon have reached maximum weight when they arrive there. Only there is it possible to identify different races of salmon and manipulate fishing effort for each so as to allow optimum escapement up river for maximum stock renewal.

\footnotetext{
4 For a more extensive unalysis see copes $(1977)$.
} 
Most of the North American Pacific salmon stocks travel well beyond the 200-mile limit on their feeding migration in the North Pacific, where they are potentially subject to a high seas fishing operation by foreign fleets. In the Law of the Sea Conference discussions leading to the drafting of the ICNT, several states of origin for salmon (and notably Canada and the United States) urged that the proprietary rights of states of origin in respect of anadromous stocks be recognized and that high seas fishing for them be prohibited. However, the number of states of origin is small in relation to the number of states with an actual or potential interest in lishing for salmon on the high seas, or no interest at all in the question of anadromous stocks. A compromise was reached and a provision included in the ICNT which stated that no harvesting of anadromous fish should take place outside the 200-mile zone "except in cases where this provision would result in economic dislocation for a state other than the state of origin." This has been held to mean that existing high seas fisheries for salmon could continue, but that no new high seas fisheries for salmon should be commenced.

Japan is the only country so far that has engaged in any signilicant high seas fishing for Pacific salmon from North America. However, under the terms of the International Convention for the High Seas Fisheries of the North Pacific, concluded in 1952 by Canada, Japan and the United States, Japan agreed to abstain from fishing for salmon cast of $175^{\circ} \mathrm{W} .{ }^{12}$ Very few salmon from British Columbia and the American states to the south migrate past this "abstention" line, so that the Japanese high seas fishery is confined almost entirely to salmon of Asian and Alaskan origin.

It should be noted that the ICNT strictures on high seas fishing for salmon are practically unenforceable and would be so even if the ICNT were adopted by an international convention. For international law applies only to states that voluntarily submit to it. While coastal states may be expected to enforce their fishery jurisdiction within their 200-mile zones, it is unthinkable that Canada, or any state, should attempt to police ICNT rules on the high seas. It is conceivable that at some time Japan will renounce the 1952 Convention and extend her high seas fishery to Canadian salmon stocks. It is also possible that other countries will start a high seas fishery for Canadian salmon. ${ }^{13}$ However, the United States does have considerable economic and political leverage with countries in a good position to engage in North Pacific high seas salmon fishing, such as Japan and the Republic of Korea, and is likely to use this leverage for protection of the salmon stocks. As Canadian and American salmon are inextricably mixed on the high seas, Canada may be at "free rider" in respect of any protection that the United States would secure.

\footnotetext{
12 In a 1979 amendment to the Convention Japan agecd to further restrictions on high seas salmon fishing, including a shift of the abstention line from $175^{\circ} \mathrm{W}$ to $175^{\circ} \mathrm{E}$.

13 It should be noted that the advent of the 200 -mile linit indirectly may increase the danger of new high seas fisheries for shalmon developing. With distant wuter fishing flects being hitred from $200-m i l e$ zones around the world, they ure under additional pressure to start new fisheries in the remaining high scas, For a further discussion of this and other "perverse effects" of the 200 -mile limit on Canada's tisheries sce Copes (1979 and 1980b).
} 
Foreign Relarions in Fisheries

Canada's 1976 policy statement on fisheries referred to the imminence of the 200-mile limit, but was strangely silent regarding Canada's position vis-à-vis foreign fishing nations. This may be explained, in part, by the fact that in 1976 delicate negotiations were underway with several foreign countries, to persuade them to recognize Canada's 200-mile fishing limit in advance.

While Canada felt compelled for internal reasons to advance a strongly acquisitive position in the ongoing Law of the Sea negotiations, the country remained quite anxious to maintain cooperative relations with other fishing nations. Good foreign relations, of course, are important for various reasons of image, diplomacy and trade. But Canada has cogent reasons directly related to fisheries management as well. On both coasts the country has important fisheries that are not fully protected by the 200 -mile limit. The goodwill and cooperation of other countries is needed in respect of these fisheries.

On the Atlantic Coast it concerns stocks of groundfish that straddle, or migrate across, the outer boundary of the 200 -mile zone. Canada, in this matter, is seeking a position of respect and influence in the new Northwest Atlantic Fisheries Organization to obtain stock management regulations favourable to Canada's interests. The problem on the Pacific Coast, as indicated, is the migration of Canadian salmon stocks into the high seas. Canada succeeded in getting protective clauses written into the ICNT. But because of their unenforceability there remains a need for continuing cooperation from other countries to observe the ban on high seas salmon fishing.

Canada recognizes that her fishing interests will continue to be interdependent with those of other countries and that miversal recognition of, and adherence to, the rules of the ICNT may be mutually advantageous. This has reinforced Canada's resolve, against some domestic opposition, to demonstrate that she will adhere to the letter and the spirit of the ICNT rules on surplus stocks. Thus Canada is giving foreign fishing fleets access on reasonable terms to stocks in her 200-mile zone that are surplus to her own needs.

On the Pacific Coast the stocks that may be considered surplus are quite modest in extent, consisting of a few groundfish species and dogfish. The surplus is much smaller than the catches taken by foreign fleets during the decade. preceding the 200-mile limit. The reasons for cutting back the amount of fish made available to foreign fleets include the following:

(1) stocks of several groundfish species have been overfished and need to be restored;

(2) prime halibut fishing grounds need to be protected from the damaging effects of groundfish fishing;

(3) some effort from the Canadian halibut fleet needs to be diverted to groundfish because of the loss of access to Alaskan halibut stocks;

(4) larger groundfish catches for the domestic fleet are needed to meet a growing demand in the markets now available to Canada. 
In the three years that Canada's 200-mile limit has been in etfect catch quotas have been made available to foreign fleets for surplus stocks of hake, dogfish, blackcod and rockfish. Because of Canada's own increasing requirements, foreign rockfish quotas have been discontinued and blackcod quotas are also likely to be lerminated. "Canada has been expanding her catches of dogfish and is experimenting with a hake fishery. Surpluses of these species may continue to be available to foreign fleets for some time, though the Canadian fishing industry undoubtedly will seek to develop a capacity to utilize these stocks fully.

Canada phased in her assumed authority in the 200 -mile zone gently. In the first year (1977) foreign vessels were charged no access fees, despite the not inconsiderable management expenses incurred by Canada. The fees charged since then have been modest. Of the five distant water fishing countries that were engaged in operations off Canada's west coast, four have taken up quotas, viz. Japan, the U.S.S.R., Poland and the Republic of Korea. Fishing arrangements with the fifth, the German Democratic Republic, have been under discussion.

In an attempt to satisfy both domestic and foreign fishing pressures at the same time, Canada is seeking to experiment with cooperative fishing ventures. On the Pacific Coast the scope is quite limited. One arrangement in this category was mạde in 1978 when Canadian vessels were contracted to catch hake for direct sale and delivery at sea to Polish factory trawlers, which processed and retained the catch. The economics of this operation were less ceitain for the Polish vessels, whose catching capacity was Jeft idle, than for the Canadian vessels, which had no processing capacity and could not deliver this particularly perishable fish to shore plants in time.

Hake constitutes the only significant stock on Canada's west coast for which no domestic fishery had appeared feasible until then. ${ }^{15}$ The cooperative arrangement with Poland was therefore an attractive option to Canada in rounding out involvement of the domestic fleet in the atilization of available stocks. A continuation of the arrangement is under negotiation. Canada is exploring its possible extension to dogfish, as well as the possible involvement of additional foreign fleets.

The severely limited capacity for further expansion of the world's fish catch, in combination with reduced access to existing fisheries on account of the 200-mile limit, has greatly constrained the supply position for many countries that are large consumers of fish. Canada. on the other hand. has long been an important net exporter of fish and, as a result of the 200 -mile limit, has acquired a much increased potential as a fish producer and exporter. In 1976, before the 200-mile limit took effect, Canada stood third in the world in terms of the value

\footnotetext{
14 For a mure detailed dixcussion of toreign cutch quatas on Canida's Pacific coast see Copes (1981a).

15 A Canadian frecer trawler has since been introduced to catuh and process hake. 'l'he commercial suscess of this aperation has yet 10 be determined.
} 
of fish exports $\rightarrow$ not far behind Norway and Japan. It seems very likely that Canada now is, or will soon become, the world's leading exporter of fish products.

A natural consequence of Canada's surplus position in fish production is a keen interest on the part of fish importing countries in access to Canadian fish supplies. When the imminence of this development became apparent a few years ago, the Canadian government made it known that they would not permit the expansion of fishing operations in Canada to be undertaken by foreign interests, though the means of ensuring adherence to this edict were not made entirely clear.

A more restrictive policy on foreign investment in the fisheries sector than in the Canadian economy generally, is somewhat ironical. The Canadian fishing industry has had an historically low level of profitability and a (no doubt related) low level of foreign investment. However, by the same token, the possibilities opened up by the 200 -mile limit were indicative of an improved profit potential in the fisheries sector, which the Canadian government not unnaturally wished to reserve for Canadian residents. There were also political reasons for restricting foreign access to the fishery. There was a felt need to assert full Canadian control over the new 200-mile zone vis-a-vis the international community, and to demonstfute to domestie regional and sectional groups that their interests in the fishery were being defended.

There are obvious ways for the Canadian government to restrict foreign investment in the fisheries sector. As all fish harvesting operations are subject to limited entry licensing, the government is in a position to tum away any foreign applications for fishing licenses. In fact, the government has controlled and strictly limited direct foreign fishing by this means. Licenses for foreign vessels have been given for no more than a single season at a time. And licenses have been given only in the case of surplus stocks made available under ICNT rules or short-term cooperative arrangements, such as the one with Poland described above. The acquisition by foreign interests of existing fish processing and marketing operations in Canada is also subject to legal controls. The Foreign Investment Review Act has established an agency to assess foreign acquisition of control over resident enterprises, with the government exercising the power to reject takeover's consider ed not in the Canadian public inierest.

There remain, however, a number of avenues by which foreign interests may gain access to, or control over, fish supplies in Canada. " In fact, the amount of foreign investment in fish processing companies in British Columbia, particularly by Japan, has increased greatly since 1974. The restrictions on foreign investment do not apply to the purchase of shares or other securities which do not involve formal acquisition of control of a business. Furthermore, there is no interference with the expansion of existing foreign controlled enterprises,

\footnotetext{
10 A detailed unalysis of this subject in resped of the Aritish Coltmbia fishing industry may be found in troverbs (1978) and Quadra Fconomic Consultanis and McDinicls Rescarch (1979).
} 
including their acquisition of "small" Canadian businesses (gross assets not exceeding $\$ 250,000$ and gross revenues not exceeding $\$ 3,000,000$ ). Japanese investment activities in the fisheries sector of British Columbia in recent years have also been carried out through purchase of debentures from, and provision of working capital loans to, local processors. In addition to larger Japanese corporations, some Japanese wholesalers and smaller trading companies have entered the field, providing capital to local processors and fish buyers to secure specific supplies. By paying high cash prices they have frequently obtained substantial supplies in competition with larger Canadian and foreign companies.

Japanese fish purchases in British Columbia in recent years have been particularly strong in herring and salmon roe and in frozen whole salmon. While fishermen have been very pleased with the high prices received, a number of concerns have also emerged. The particular products demanded by Japanese purchasers require rather little processing. By diverting supplies from domestic processors, it is also complained that the competitive scramble by a multiplicity of Japanese purchasers, ready to finance small local operations tied to them, has tended to produce a wasteful excess of local handling and processing capacity. In response to the local outcry the provincial government of British Columbia imposed a moratorium on the issuance of lish buyer and processing plant licenses, ${ }^{17}$ and commissioned a report on the implications of foreign operations in the British Columbia fishing industry. The report (Quadra Economic Consultants and McDanicls Research [25]) concluded that the entry of Japanese interests had tended to increase beneficial competition in the short run and that there was no immediate danger of their domination of the market. They did not recommend any countervailing action and there is no indication that any is now contemplated. The moratorium on fish buyer licenses has meanwhile been lifted.

\section{Summary and Conchision}

The prospect of the 200-mile limit triggered a reassessment of Canada's objectives in fisheries exploitation and led to a new articulation of fisheries policy. Under the internal pressure from her coastal regions, Canada developed an acquisitive attitude with respect to the fish resources off her coasts. Possession of the fish stocks of the 200-mile zone was seen as a means of achieving economic betterment for the country's fishing communities.

It was recognized that to extract the full benefit from the 200-mile limit it would be necessary to undertake a program of socio-economic rationalization of the fisheries. Such a program was made possible only by the legal management authority that came with the claim to extended fisheries jurisdiction. Well instructed in the new economic analysis of common property fisheries problems, the Canadian government has installed limited entry licensing in all her fisheries

\footnotetext{
17 It should be noted that Cunada's federal government has primary responsibility in matters of foreign trade and investment, while the provincial government of British Culumbia has jurisdiction over the regulation and licensing of local trading and procensing operations.
} 
and is attempting to achieve optimum exploitation levels by socio-economic criteria. As the dubious results of the British Columbia salmon licensing and buyback program have shown, this does not appear to be an easy task. Fortunately, the additional fish that is becoming available to the British Columbia fishing industry by control of the 200 -mile limit and by the salmon enhancement program should allow better use to be made of the existing fishing capacity. It is therefore reasonable to expect improved economic returns.

With respect to the interface with foreign interests in lisheries operations off Canada"s coasts, the government has issued no single comprehensive and explicit policy statement. Nevertheless, the characteristics of Canadian policy in this regard can be readily discerned from the government's actions and pronouncements. The following appear to be major elements of this policy.

(1) The restoration of overfished stocks and the supply requirements of the domestic fishing industry will be given first priority in the allocition of fish resources.

(2) Canada seeks cooperation with other fishing countries in managing transboundary stocks and in securing compliance with the atsention from high seas salmon fishing.

(3) Special management agreements will be sought with the United States to secure maximum joint benefits - and equitable distribution thereof for their overlapping and iisteracting fisheries. Generally, each country ${ }^{+}$s fleet will be confined to its national waters.

(4) Canada will observe the letter and the spirit of the ICNT requirement to make surplus stocks available on reasonable terms to foreign fleets.

(5) In allocating surplus stocks to foreign fleets Canada will give preference to cooperative arrangements that beneficially involve the Canadian industry.

(6) Increased direct foreigu ilivestivent in Cantdian fishing and figh processing operations, generally, is to be avoided, though some foreign investment linked to fish export operations will be tolerated.

Until 1965 fishing on Canada's west coast was limited to the exploitation of high-value species by Canadian and American vessels from nearby shore bases. The increased world demand for lishl lias since caused a fuller exploitu tion of available west coast stocks and has attracted foreign fleets in the process. The national policy that Canada has developed in response to the opportunities of the 200 -mile limit, is gradually diverting the fishery for all species to the Canadian fleet. The prospect is that henceforth the available resources will be fully exploited. It appcars likely, however, that, with negligible exceptions, fishing on Canada's west coast will become a domestic operation entirely.

\section{REJERENCFS}

[1] Aell, Frederick W. 1972. "'Technolighical Externalitics und Common-l'skperty Resources: An Empirical Sudy of the U.S. Northern I Aobster Fishery." Iowrnal of Politidal Economy. Vol. $80,1 \%, \mathrm{pp}, 148-15 \%$. 


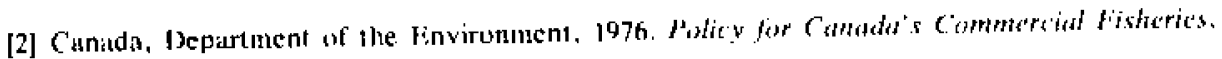
Ottawa.

[3] Canadi. Department of Fisheries and the Environment, 1978a. The Salmonid Enhamiement Pregram, Valuconver.

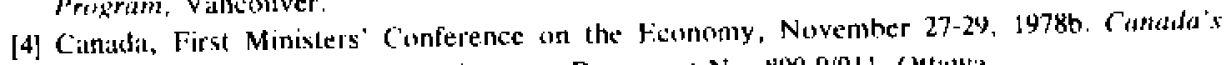

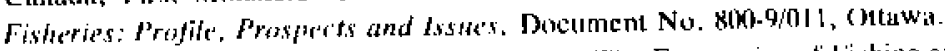

[9] C.lark. Cohin W. and (istudun R. Munco, 1975. "'l he Feonomics of Fishing and Mostern Capital

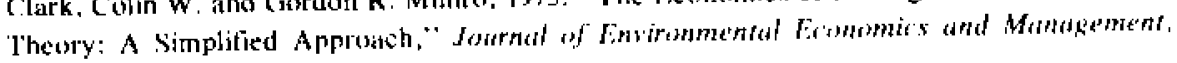
Vol. 2, pp. 92-106.

[6] Copes. Parzival, 1472. "Fater Rents, Sule Ownership and the Optinum level of Fisherics

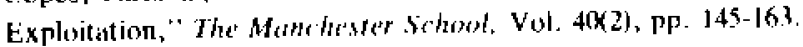

[7] Copes, Pazival, 1977. "The Law or the Sca and Management of Anatrormous lish Stok'ks,"

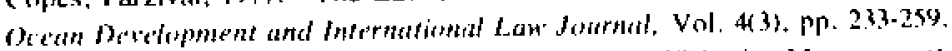

[8] Copes, Parziva, 1979. "The Pcotwomics of Marine lisheries Management in the kira of Extended Jurisdiction: The Canadian Perspective." Amerion licomomic Reviete, Papers and l'Tocecedings, Vol. 69(2), pp. 2.56-260).

[9] Copes, Purcival, 1980a. "The Evolulion of Marine Fisheries Policy in Cannda," Jonrmat of Busints. Adminictration. Vol. II (1/21, $\mathrm{pp}$. 129-148.

[10] Copes, ["wzival, 1980h, "Hribish Columbia J'isheries and the 200-Mile I imit: Perverse Eflects lor the Coitstal State," Marine Policy. Vol. 4(3), Pp. 205-214.

[11] Copes, Parzival, 1981a. "Marine fisheries Martagement in Canidat ]olicy Objectives and Institutionul Constrints," in Unive rsity ur Rhode Islintl, Fenter for Ocein Managemest Studies. Comparativid Marine Policy. Clı. Il, New York. Pt'steger.

[12] Copes, Parzivd, 198ih. "Eisheries Management on Caniula's lacilic Cuast: The lmpate we Fxtended Jurisdiction on Jixpluitation Pattems." Otran Manakenert, Vol. 7.

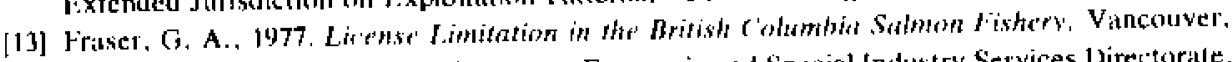
Canada, Deparment of the Fnvironment. Economic and Special lndustry Services Directorate. Pacitic Kctgion.

[14] Fr'tser, G, A., 1979, "I.imited Entry: Faperience ol the Hritish Columbia Sulmon Fishery."

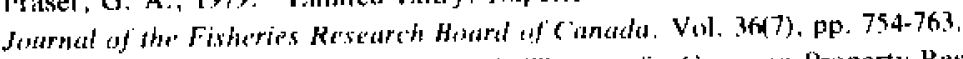

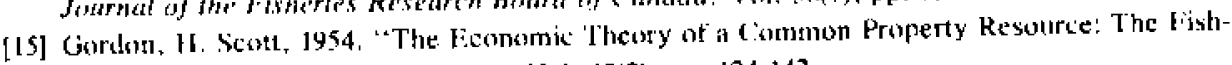
ery," Journal of Pulitical fironormy, Val, 62(2), pp. 124-142.

[16] Gollicb, Allan, and Charles Dulfen, 1973. "Nationat Jurisdiction and Intemationt Responshility: New Cunadian Appronches to International Law." Amorican Journal of Infornationtl Ian', Vul. 67, Pp, 229-25k.

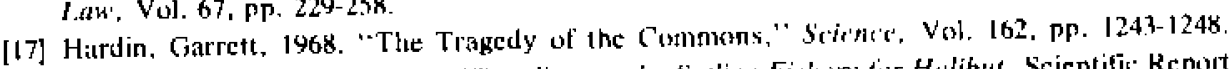

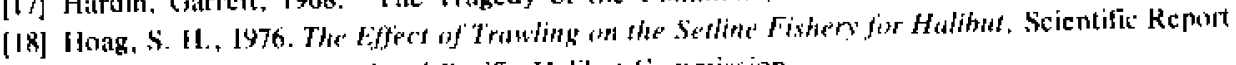
No. 61. Scatte. Intenational Pacifie Halibut Commission.

[19] Juhnson, Barbasa, 1977. "Canadian Foreign Policy and Fisheries," in Barbara Johnson and

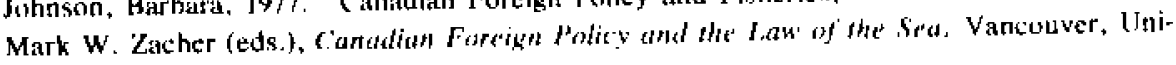
versity of British Columbia Press.

[20] Koers, Albert W., 1973, International Krgulation of Marini Fisheries, London, Fishing News (Hooks) Lid.

[21] MasEachan, Allan J., 1976. Mansard, June 4, 1976, 14164.

[22] Jearse, Peter H., 1972, "Rationalization of Canada's West Coust Sulmon likhery: An Fennomic F.valuation," Economic Aspects of' Fish Production. Patis, OEC'D.

[23] Pearse, P. H., and J. E. Wilen, 1979. "Impact of Canada's Pacific Salmon Fleet Control Pro-

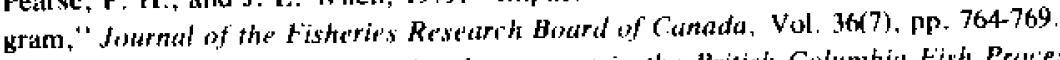

[24] Proverhs, Trevor B., 1978. Foreign Investment in the Britist Columbia Fish Protessing Inawstry, Vancouver, Canudu, Department of Fisheries and the Environment, Pucific Region, Fisheries and Muritue Service Industry Reporn No. 105.

[2.5] Quadra Bconomic Consultants Lid. ind MeDanicls Reseisch I.td., 1979. Fore'ign Integtmicht 
in Brisinh Cohmbia Fish Processing, prepared tor lat Brilish Columbia Ministry of Erviron. ment, Victoria.

[26] Sinulair, Sol, 1960. License I.mitarion - Brisixh Cohmbia: A Method of Economic Fishories Mamanemom. Otliwa, Canata. Depurtment of Fisheries.

[27] IJnited Nations, Third Canference on the $\mathrm{L}$ aw of the Sea, 1979. Informal Composite Negi-

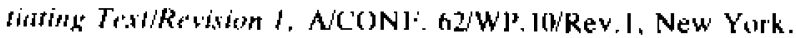

